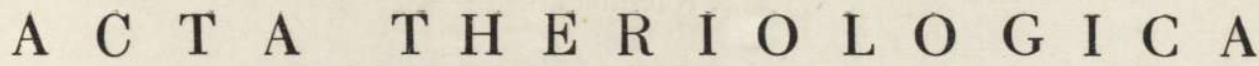 \\ VOL. XI, 19: 409-417. \\ BIAEOWIEŻA \\ 15.XII.1966
}

\author{
Franciszek K A C Z M A R S I
}

\section{Bioenergetics of Pregnancy and Lactation in the Bank Vole ${ }^{1}$ )}

[With 1 Table \& 1 Fig.]

\begin{abstract}
The food consumption and assimilation were determined in the females of bank vole, Clethrionomys glareolus (S chreber, 1780) during the whole period of pregnancy and lactation $(18+18$ days). The daily food assimilation (digestion) of non-reproducing females (body weight $25 \mathrm{~g}$ ) is $17.5 \mathrm{Kcal} / \mathrm{animal}$. Toward the end of gestation it reaches $23.7 \mathrm{Kcal} /$ day/animal and during the maximal lactation it averages $38.9 \mathrm{Kcal} /$ day for the females of the same body weight. The energy requirement of females increases by $24 \%$ during the pregnancy and $92 \%$ during the lactation. To produce a litter of 5 young and raise 4 of them to weaning a female has to assimilate additionally $364 \mathrm{Kcal} ; 75$ for the pregnancy and $289 \mathrm{Kcal}$ for the lactation. The increase in food intake during this period corresponds to $406 \mathrm{Kcal}$. The digestibility coefficient is high in both non-reproducing and pregnant or lactating females $(88.5 \%)$. The ecological efficiency is also very high; $11.8 \%$ during the pregnancy and $14.6 \%$ during the lactation. In the models of rodent bioenergetics the correction for gestation and lactation has to be considered. These corrections are computed for whole breeding season in relation to the number of mature females in the population.
\end{abstract}

\section{INTRODUCTION}

The slight increase of the food requirements during the pregnancy and very sharp increase during the lactation have been described in domestic cattle (B r o$d y, 1945)$. The similar differences in the human are reflected by different dietary allowances for pregnant and nursing women (Szczygiel, et al., 1965). The twoor three-fold increase of food intake during the lactation (as compared to the gestation) have been described in rats and mice (Brody, 1945; N els on \& Evans, 1961; Fell, Smith \& Campbe11, 1963; Barnet \& Little, 1965). Therefore, a comparable situation was to be expected in the wild rodents. Determining the energy requirements during the pregnancy and lactation is very important for constructing the bioenergetic models of these animals (D a vis \& Golley, 1963).

The purpose of this study was to determine the food intake and food assimilation in the females of bank vole, Clethrionomys glareolus (S chre be r, 1780)

1) This work was carried out under the International Biological Programme in Poland. 
during the whole period of gestation and lactation. The bank vo'e is a dominating rodent species in the european forest ecosystems. There are extensive data on its reproduction (Sviridenko, 1959; Petrov \& Airapetyants, 1961; M a$\mathrm{z}$ a k, 1962) metabolic rate and bioenergetics (Janský, 1959; Grodzinski, 1961; 1962; Vis in e s c u, 1965).

\section{MATERIALS AND METHODS}

The animals used for experiments were from the laboratory strain of bank voles maintained for seven generations by brother-sister matings (D rożd ż, 1963). The females were paired singly with the males and the vaginal smears were taken daily. The day when the plug was found was considered the beginning of pregnancy (S ne 11, 1956). The females that mated were placed singly in metal two-chamber cages $(42 \times 25 \times 16 \mathrm{~cm})$ and kept without a male for the period of pregnancy and lactation i.e. for nearly six weeks. In the bank vole mean length of gestation is 18 days and females are lactating for about three weeks, with the young starting to eat solid food when 17-18 days old (Sviridenko, 1959; Petrov \& Airapety ants, 1961). The cages with the experimental animals were kept in a separate room with the temperature about $20^{\circ} \mathrm{C}$ with the light rhythm $12 \mathrm{~L}: 12 \mathrm{D}$.

The daily food consumption was determined by the "food ration" method. The voles were given wheat $(10 \mathrm{~g})$, carrots $(15-25 \mathrm{~g})$ and milk $(15-30 \mathrm{ml})$. Every 24 hours the consumption of wheat and carrots was determined by weighing and the consumption of milk by reading the level on the calibrated bottle. The corrections for the drying of fosd were considered in the calculations. The caloric value of wheat and carrot samples was determined in the calorimetric bomb, also the water and ash contents were determined (Górecki, 1965). Similar data for the milk were computed from its chemical composition (S pector, 1956). The total of 10 complete periods of gestation and lactation were studied in 10 adult females. The caily food consumption of ten different non-reproducing (i.e. non-pregnant and non-lactating) females was studied as a control.

In a separate series of experiments the digestibility coefficient of the used diet was measured in non-reproducing, in pregnant and in lactating females. The females were placed singly in similar cages equipped with double bottom. The food consumption and feces excretion were determined during five consecutive days. The samples of dry feces were then burned in the calorimetric bomb. The caloric loss in urine was disregarded.

\section{RESULTS}

The energy flow through the individual organism or through the population equals the assimilated energy i.e. the energy consumed with food minus the energy value of excretions (feces and urine). In this paper the term "assimilated energy" is used to describe the consumed food minus the feces disregarding the urine. "Digested energy" would be a more precise term. All results are expressed in "digested energy" and consequently, the digestibility coefficient of the diet had to be determined.

The non-reproducing females were consuming, on the average, $2.32 \mathrm{~g}$ of wheat, $7.08 \mathrm{~g}$ of carrot and $5.44 \mathrm{ml}$ of milk daily. It was determined 
that the caloric value of wheat was $4636.6 \mathrm{cal} / \mathrm{g}$ of dry weight and the caloric value of carrots $3983.8 \mathrm{cal} / \mathrm{g}$ of dry weight. The water content of wheat was $14.2 \%$ and that of carrots $81.9 \%$. Therefore the caloric value of fresh carrots was $0.810 \mathrm{Kcal} / \mathrm{g}$ of biomass (fresh weight) and that of fresh wheat $3.979 \mathrm{Kcal} / \mathrm{g}$ of biomass. The caloric value of milk with $2 \%$ fat content was calculated as $0.570 \mathrm{Kcal} / \mathrm{ml}$. The female having an average body weight $(19.5 \mathrm{~g})$ was consuming about $17.48 \mathrm{Kcal} /$ day. The caloric loss in feces was $2.01 \mathrm{Kcal} /$ day. (The caloric value of vole feces is $4.590 \mathrm{Kcal} / \mathrm{g}$ of dry weight). From the above data it was computed that the digestibility coefficient of used diet was $88.5 \pm 2.4 \%$ in non-reproducing females. Similarly high is the digestibility coefficient in pregnant and lactating females in spite of considerably higher food intake. During the period of most intensive milk production (second week after parturition) the digestibility coefficient was $86.2 \%$ and was not significantly different from the value obtained in non-reproducing females. Consequently, the digestibility coefficient $88.5 \%$ was used for all calculations in the present study. This coefficient is 2 to $4 \%$ too high because the energy excreted in urine was not considered ( $\mathrm{D}$ o $\dot{z} \mathrm{~d} \dot{z}$, in litt.).

The daily food assimilation was determined in the series of control non-reproducing females. Their mean body weight was $24.5 \mathrm{~g}$. These animals were consuming $2.14 \mathrm{~g}$ of wheat, $8.84 \mathrm{~g}$ of carrots and $6.7 \mathrm{ml}$ of milk daily. In this way they were assimilating $17.25 \pm 1.31 \mathrm{Kcal} / \mathrm{animal}^{\prime}$ iday. This metabolic rate corresponds to $0.704 \mathrm{Kcal} / \mathrm{g} /$ day being 5 to $10 \%$ higher than the value of metabolism obtained from the respirometry ( $G$ rodzinski, 1961). Consequently, it can be assumed that the bioenergetics of a large, $25 \mathrm{~g}$ female vole, non-pregnant and non-lactating amounts to $17.5 \mathrm{Kcal} /$ day. The energy assimilated during the gestation and lactation can be compared with this value.

The values of food assimilation during the pregnancy and lactation which will be discussed represent the average of 10 studied females. Their mean body weight at mating was $25 \mathrm{~g}$. The mean litter size was 5.0 (from 3 to 7 ) at birth and 4.0 (from 3 to 6 ) at weaning.

The increase of food consumption was much smaller during the pregnancy than during the lactation. The curve of food assimilation rose slowly and gradually during pregnancy but went up very steeply during lactation reaching a very high level (Fig. 1). The mean daily energy assimilation increased to $21.8 \mathrm{Kcal} /$ female on the 6 -th day of pregnancy, then remained relatively stable for about a week and during the 15 th and 16 th day reached the highest pregnancy value, $24.32 \mathrm{Kcal}$. The 18 day period of gestation was arbitrarily divided into three 6 day parts (Table 1). Considering the control value $(17.5 \mathrm{Kcal}$ for non-re- 
producing female) as $100 \%$, the mean food assimilation during the first six days of gestation was $117.3 \%$, between the 7 th and 12 th day $121.8 \%$, and $135.25 \%$ between the 13 th and 18 th day.

The parturition caused short but distinct depression in food assimilation (Fig. 1). During the last day of gestation the energy assimilation fell to $23.43 \mathrm{Kcal} /$ day and during two following days when the female was already lactating it was still smaller $(22.47 \mathrm{Kcal})$. In the sub-

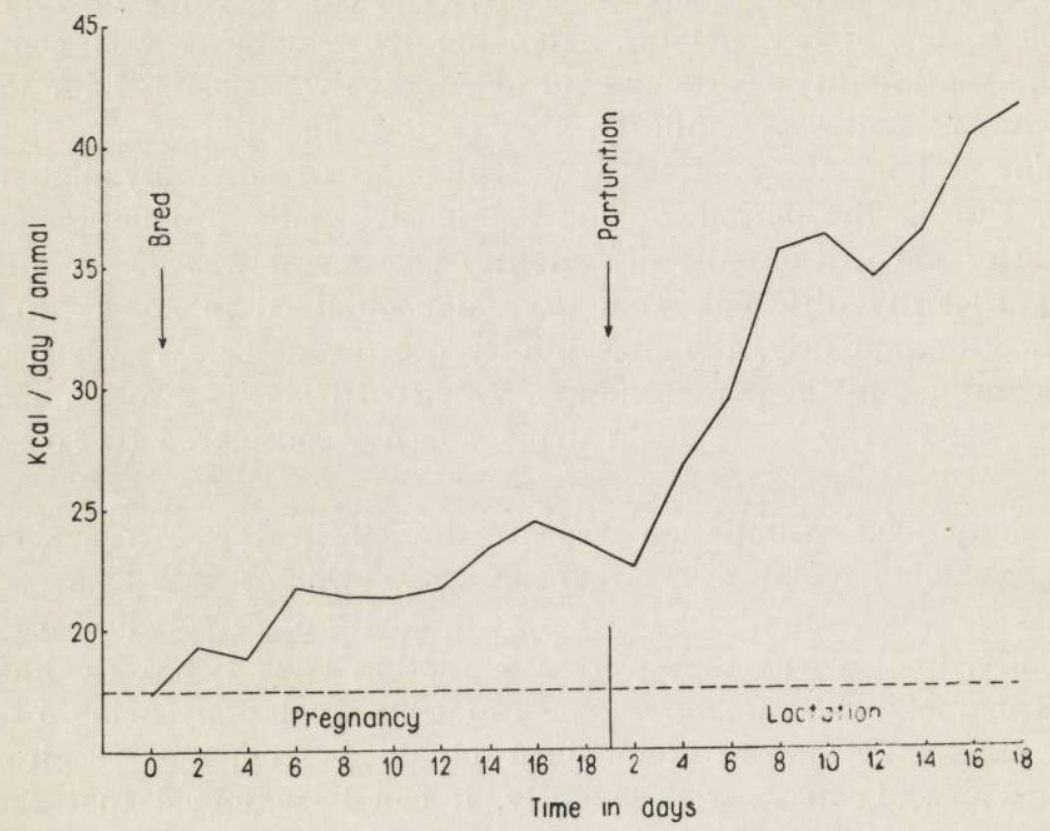

F'ig. 1. Daily food assimilation of female bank voles during pregnancy and lactation. Curve represents the mean of 10 studied females. The average level of energy assimilation in non-reproducing females of the same size $(17.5 \mathrm{Kcal} / \mathrm{day})$ is marked with broken line.

sequent days of lactation the food consumption of nursing females increased sharply. This is especially true from day 2 to day 8 after the parturition, when the increase of the weight of the young was very rapid. The food assimilation reached the mean of $35.59 \mathrm{Kcal} /$ animal on the 8 -th day of lactation and then stayed for a few days on this level. Another increase of food intake began on the 12th day of lactation and the maximal value of $41.52 \mathrm{Kcal} /$ animal was reached on the 18 th day. The mean energy requirement during three 6 day periods of lactation (Table 1) was $150.22 \%, 205.48 \%$ and $222.57 \%$ as compared with the metabolic rate of control females.

The total amount of additionally used energy during gestation and lactation can be approximately estimated from these data. During the 
18 days of gestation the female vole assimilated the total of $389.72 \mathrm{Kcal}$. A non-reproducing female with the same body weight used $315 \mathrm{Kcal}$ during the 18 day period. The difference, probably used for the pregnancy itself was $74.72 \mathrm{Kcal}$. During the 18 days of lactation the female vole assimilated $604.15 \mathrm{Kcal}$ i.e. $289.15 \mathrm{Kcal}$ more than the non-reproducing female. Consequently, the "cost" of producing and raising a litter $(\overline{\mathrm{x}}=$ $=5$ at birth and 4 at weaning) corresponds to the additional assimilation of $364 \mathrm{Kcal}$ in food consumed during the 36 day period of gestation and lactation. The mean energy requirement of a pregnant female vole was increased by $24 \%$ and in a nursing female vole by $92 \%$. Generally it can be assumed that the energy requirement of the female during both pregnancy and lactation is, on the average, increased by $58 \%$.

\section{Table 1.}

Daily food assimilation of female bank voles during pregnancy and lactation. Each mean represents 10 females.

\begin{tabular}{|r|c|c|}
\hline \multirow{2}{*}{$\begin{array}{c}\text { Time } \\
\text { in days }\end{array}$} & \multicolumn{2}{|c|}{ Daily food assimilation in Kcal/day/animal } \\
\cline { 2 - 3 } & Pregnancy Mean \pm S.D. & Lactation Mean \pm S.D. \\
\hline $1-6$ & $20.53 \pm 3.01$ & $26.29 \pm 4.32$ \\
$7-12$ & $21.19 \pm 2.07$ & $35.96 \pm 7.66$ \\
$13--18$ & $23.67 \pm 3.32$ & $38.95 \pm 8.92$ \\
\hline
\end{tabular}

The value of additional $364 \mathrm{Kcal}$ during the pregnancy and lactation corresponds to the ingested energy. Considering the energy excreted with the urine, the amount of food additionally assimilated during this period would be about $352 \mathrm{Kcal}$. However, the total amount of food consumed additionally during the gestation and lactation amounts to $406 \mathrm{Kcal}$, as it is $11.5 \%$ higher than the ingested energy.

\section{DISCUSSION}

The rapid increase in food consumption during the lactation and some increase during the pregnancy coincides with distinct changes in the alimentary tract of the female. Such changes were described in reproducing laboratory rats (Fell et al., 1963), bank voles and field mice, Apodemus flavicollis (M l l chior, 1834), (M y rcha, 1964; 1965). The weight and length of different parts of the alimentary tract are temporarily increased ( $\mathrm{M} \mathrm{y} \mathrm{c} \mathrm{h}$ a, l. c.); hypertrophic and hyperplastic changes in the intestine walls were reported (Fell et al., $l$. c.). This allows to maintain the digestibility coefficient during pregnancy and lactation on a normal level. 
During the lactation in the bank vole there is a correlation between the rate of the growth of litter and the increase of food consumption by the female. The rate of development of young voles changes during the period of lactation. According to Pears on (1962) it is nearly twice as high during the second half of lactation. Similar differences in the growth rate can be calculated from the data of Sviridenko (1959), Petrov \& Airapetyants (1961) and Mazà (1962). The curve of growth of the young raises sharply at about the 12th day of postnatal life i.e. when the young begin to see and move around. The food consumption of a nursing female vole is increased maximally during this period (12th to 18th day of lactation) (Fig. 1).

The efficiency of reproductive processes in the bank vole is extremely high. It can be estimated by comparing the increase in the weight of litter (i.e. "production") with the energy additionally assimilated by the female during this period. The net production of young in one litter is about $8.24 \mathrm{Kcal}$ (together with the placentae and fetal membranes 10.30 Kcal). For these calculations the mean litter size of 5 was used with new-born voles weighing $1.6 \mathrm{~g}$ each (D rożd $\dot{z}, 1963$; Petrov \& A irapetyants, 1961) and the caloric value of new-born vole 1.03 $\mathrm{Kcal} / \mathrm{g}$ (G ó recki, 1965). During the pregnancy the female additionally assimilates nearly $75 \mathrm{Kcal}$. Consequently, the efficiency (the food assimilated in relation to the production) is $13.8 \%$ considering the placentae and membranes and $11.0 \%$ considering the baby-voles alone.

The efficiency during the lactation period is even higher. The young grow on the average from 1.6 to $9.0 \mathrm{~g}$ (P etrov \& Airapetyants, 1961 ; D rożd $\dot{z}, 1963)$ and the mean of four young is raised to weaning. Consequently, the production of their body is $29.6 \mathrm{~g}$ or $42.3 \mathrm{Kcal}$ ( $\mathrm{G}$ órecki, 1965). The comparison of this value with $262 \mathrm{Kcal}$ additionally assimilated during the lactation results in the efficiency of $14.6 \%$. Since two separate trophic levels are involved (female and the young) this efficiency is exceptionally high. It can be explained by the very high caloric value of the milk in small rodents (S pe ctor, 1956).

The energy requirement of reproducing females increases so drastically that in the models of rodent bioenergetics corresponding corrections have to be considered. These models are usefull for the calculation of energy flow through the rodent populations. The corrections for pregnancy and lactation can be estimated in one of the following ways: (1) Adding for every litter the average of $350 \mathrm{Kcal}$ of assimilated energy or $400 \mathrm{Kcal}$ of consumed food; (2) Adding the mean of $58 \%$ to the bioenergetics of reproducing females during the breeding season.

In both cases it is assumed that the actual "expenses" for gestation and lactation are similar to the values obtained in the laboratory. It 
appears that they are at least not higher. In the laboratory mice the increase in food consumption during pregnancy and lactation is lower in the temperature of $-3^{\circ} \mathrm{C}$ than in the room temperature (B a r n e t $t$ \& Little, 1965).

The corrections mentioned above should be considered during the whole breeding season but only in relation to the mature and reproducing females. In the natural population of voles the number of breeding females as well as the number of litters are very difficult to estimate. The reproduction takes place during a period of 6 to 7 months but only a proportion of females is involved. The proportion of reproducing females is different in different age groups and changes from

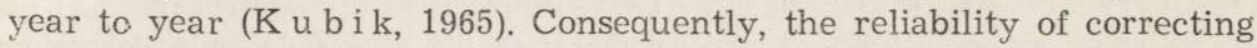
the energy balance of the population for the energy expenses connected with reproduction, depends predominantly on the accuracy of data on the reproduction itself.

Acknowledgements: The author wishes to express his sincere thanks to Dr. W. $\mathrm{Grodzinski}$ for suggesting the problem, continuous guidance throughout this study and help in writing, as well as to A. Gó recki and A. Drożd ż for their help and many useful suggestions.

\section{REFERENCES}

1. Barnett S. A. \& Little M. J., 1965: Maternal performance in mice at $-3^{\circ} \mathrm{C}$ : food consumption and fertility. Proc. Royal Soc. B., 162: 492-501.

2. Brody S., 1945: Bioenergetics and growth. Reinhold Publ. Corp., 1-1023. New York.

3. Davis D. E. \& Golle y F. B., 1963: Principles in mammalogy. Reinhold Publ. Corp., 1-335. New York.

4. Drożd ̇̇ A., 1963: Clethrionomys glareolus Schreber, 1780 - a new experimental animal. Zwierz. Lab., 1: 86-102. (In Polish with English summ.).

5. Evans H. M., 1961: Metabolic disturbances associated with lactation. [In "The mammary gland and its secretion", ed. by Kon S. K. \& Cowie A. T.], 2: 380-391. Academic Press, New York - London.

6. Fell B. F., Smith K. A. \& Campbel1 R. M., 1963: Hypertrofic and hyperplastic changes in the alimentary canal of the lactating rat. J. Pathol. Bacteriol., 85, 1: $179-188$.

7. Górecki A., 1965: Energy values of body in small mammals. Acta theriol., 10, 23: 333-352.

8. Górecki A., 1965: The bomb calorimeter in ecological research. Ekol. pol. B 11, 2: 145-158. (In Polish with English summ.).

9. Grodziński W., 1961: Metabolism rate and bioenergetics of small rodents from the deciduous forest. Bull. Acad. Sci. Pol., Cl. II, 9, 12: 493-499.

10. Grodziński W., 1962: Influence of food upon the diurnal activity of small rodents. Symp. theriol.: 134-140. Praha.

11. J à n $\mathrm{s} \mathrm{k}$ ý L., 1958: Working oxygen consumption in two species of wild rodents (Microtus arvalis, Clethrionomys glareolus). Physiol. bohemoslov., 7, 5: 427478. 
12. Kubik J., 1965: Biomorphological variability of the population of Clethrionomys glareolus (S c h reber, 1780). Acta theriol., 10, 10: 117-179.

13. M a z à k V., 1962: Zur Kenntnis der postnatalen Entwicklung der Rötelmaus, Clethrionomys glareolus Schreber, 1780 (Mammalia, Microtidae). Acta Soc. Zool. Bohemoslov., 26, 1: 77-104.

14. M y r cha A., 1964: Variations in the lenght and weight of the alimentary tract of Clethrionomys glareolus (S chreber, 1780). Acta theriol., 9, 10: $139-148$.

15. Myrcha A., 1965: Lenght and weight of the alimentary tract of Apodemus flavicollis (M e l ch i o r, 1834). Acta theriol., 10, 16: 225-228.

16. Pearson A. M., 1962: Activity patterns, energy metabolism, and growth rate of the voles Clethrionomys rufocanus and C. glareolus in Finland. Ann. Zool. Soc. 'Vanamo', 24, 5: 1-58.

17. Petrov O. V. \& Airapetyants A. E., 1961: On the reproduction and the first stages of postembryonal development in the bank vole under laboratory conditions. Vestn. Leningr. Univ., 21, 4: 51-61. (In Russian with English summ.).

18. Snell G. D., 1956: Reproduction. [In "Biology of the laboratory mouse" ed. by Sne 11 G. D.]: 53-88. Dover Publ. Inc., New York.

19. Spector W. S. (Ed.), 1956: Handbook of biological data. Tabl. 34 and 35 . W. B. Saunders Comp., Philadelphia - London.

20. Sviridenko P. A., 1959: The growth and development of the vole, Clethrionomys glareolus Schreb. Zool. Ž., 38, 5: 756-766.

21. Szczygieł A., Siczkówna J. \& Nowicka L., 1965: Normy wyżywienia dla osiemnastu grup ludności. P.Z.W.L. 1-114. Warszawa.

22. Visinescu N., 1965: Researches on nicthemeral and seasonal variations of energetic metabolism in Clethrionomys glareolus and Apodemus sylvaticus. Rev. Roum. Biol.-Zoologie, 10, 3: 183-189. Bucarest. In proof added:

23. Nels on M. M. \& Evan s H. M., 1961: Dietary requirements for lactation in the rat and other laboratory animals. [In "Milk: the mammary gland and its secretion", ed. by Kon S. K. \& Cowi e A. T.], Academic Press, 2: 137-191 New York - London.

Received, May 7, 1966.

Department of Animal Genetics

and Organic Evolution,

Jagiellonian University,

Kraków 2, Krupnicza 50, Poland.

Franciszek KACZMARSKI

\section{BIOENERGETYKA CIAZŻY I LAKTACJI U NORNICY RUDEJ}

\section{Streszczenie}

U samic nornicy rudej, Clethrionomys glareolus (S chreber, 1780) określano zużycie pokarmu i energię strawioną (asymilację) w ciągu całego okresu ciąży i laktacji (18+18 dni). U nie rozradzających się samic, o ciężarze ciała $25 \mathrm{~g}$, dobowa asymilacja energii wynosi średnio $17,5 \mathrm{Kcal} /$ zwierzę. W okresie ciąży zapotrzebowanie energetyczne wzrasta stopniowo i nieznacznie, natomiast $\mathrm{w}$ czasie laktacji podnosi się gwałtownie i osiąga bardzo wysoki poziom (Fig. 1). W końcowym 
okresie ciąży dochodzi ono średnio do $23,7 \mathrm{Kcal} /$ dzień/zwierzę, a w okresie maksymalnej laktacji osiąga przeciętnie aż $38,9 \mathrm{Kcal} /$ dzień, u samic o tym samym ciężarze ciała (Tab. 1). Bioenergetyka samic w ciągu całej ciąży wzrasta średnio o $24 \%$, natomiast samic karmiących o $92 \%$.

Aby urodzić miot złożony z 5 młodych i spośród nich odchować 4, samica musi dodatkowo przyswoić $364 \mathrm{Kcal}$, z czego na ciążę przypađa zaledwie $75 \mathrm{Kcal}$, natomiast na laktację aż $289 \mathrm{Kcal}$. Pokarm dodatkowo pobrany w okresie ciąży i laktacji odpowiada $406 \mathrm{Kcal}$. Wykorzystanie pokarmu jest wysokie zarówno u samic nie rozradzających się, jak także ciężarnych i karmiących (współczynnik strawności $=88.5 \%$ ). Bardzo wysoka jest także ekologiczna wydajność okresu laktacji $(14.6 \%)$ i ciąży $(11.8 \%)$.

W modelach bioenergetyki gryzoni trzeba uwzględniać poprawki na ciążę i laktację, które w całym okresie rozrodu dolicza się w stosunku do liczby dojrzałych, rozradzających się samic. 